\title{
Manajemen Pembelajaran Daring Di Perguruan Tinggi Pada Masa Pandemi Covid-19
}

\author{
Nina Herlina \\ nitatamansampurna@gmail.com \\ Program Studi Manajemen, Fakultas Ekonomi, Universitas Galuh Ciamis, Jl. R.E. \\ Martadinata No. 150 Ciamis
}

\begin{abstract}
The conventional learning pattern in higher education has changed to learning based on the global disaster of the covid-19 outbreak. Every university manager, both public and private, needs a solution to answer these problems. The research objective was to obtain an overview of the implementation of Online Learning Management in Higher Education during the Covid-19 Pandemic in Management Study Program, Faculty of Economics, Galuh Ciamis University. Data were collected by interview via google form and zoom cloud meeting. Data analysis was performed using interactive analysis techniques Miles \& Huberman. The results showed that lecturers in learning management in tertiary institutions during the Covid-19 pandemic were: 1) innovating and designing complete lectures, 2) varying learning methods, 3) platforms or applications that match the course material, and 4) communication good with students, 5) can minimize the waste of the cost of the daring lecture quota.
\end{abstract}

\section{Keywords: management, brave chase, college, covid -19 pandemic.}

\begin{abstract}
Abstrak
Pola pembelajaran konvensional di perguruan tinggi berubah ke pembelajaran daring seiring adanya bencana global wabah pandemic covid-19. Setiap pengelola perguruan tinggi baik negeri maupun swasta diperlukan solusi untuk menjawab permasalahan tersebut. Tujuan penelitian adalah untuk memperoleh gambaran pelaksanaan Manajemen Pembelajaran Daring Di Perguruan Tinggi Pada Masa Pandemi Covid-19 di Prodi Manajemen Fakultas Ekonomi Universitas Galuh Ciamis. Data dikumpulkan dengan wawancara melalui google form dan zoom cloud meeting. Analisis data dilakukan menggunakan teknik analisis interaktif Miles \& Huberman. Hasil penelitian menunjukkan bahwa keberhasilan dosen dalam manajemen pembelajaran di perguruan tinggi pada masa pandemic covid-19 yaitu: 1) inovasi dan mendesain perkuliahan secara lengkap, 2) bervariasinya metode pembelajaran, 3) flatform atau aplikasi yang sesuai dengan materi perkuliahan, dan 4) adanya komunikasi yang baik dengan mahasiswa, 5) dapat meminimalisir kendala biaya kuota perkuliahan daring.
\end{abstract}

Keyword: Manajemen, pembejaran daring, perguruan tinggi, pandemic covid -19. 


\section{PENDAHULUAN}

Pandemi corona virus disease 2019 atau Covid-19 yang telah melanda 215 negara di dunia, hal tersebut memberikan tantangan bagi setiap aspek kehidupan di dunia dari mulai tersendiri, kesehatan, politik, ekonomi dan khususnya bagi lembaga pendidikan Perguruan Tinggi. Untuk antisipasi penyebaran dan melawan Covid-19 Pemerintah telah melarang untuk berkerumun, pembatasan sosial (social distancing) dan menjaga jarak fisik (physical distancing), memakai masker dan selalu cuci tangan (Sadikin A, Hamidah A, 2020) . Corona Virus Disease 2019 (COVID-19) pertama kali ditemukan di kota Wuhan, China pada akhir Desember 2019. Virus ini menular sangat cepat dan telah menyebar hampir ke semua negara, termasuk Indonesia, hanya dalam waktu beberapa bulan saja. Sehingga WHO pada tanggal 11 Maret 2020 menetapkan wabah ini sebagai pandemi global, Harnani, (2020).

Melalui Kementerian Pendidikan dan Kebudayaan Pemerintah telah melarang perguruan tinggi untuk melaksanakan perkuliahan tatap muka (konvensional) dan memerintahkan untuk menyelenggarakan perkuliahan atau pembelajaran secara daring (Surat Edaran Kemendikbud Dikti No. 1 tahun 2020). Perguruan tinggi dituntun untuk dapat menyelenggarakan pembelajaran secara daring atau on line (Firman, F., \& Rahayu, S., 2020). Tidak sedikit universitas dengan cepat merespon intruksi pemerintah, tidak terkecuali Universitas Indonesia (UI) dengan mengeluarkan surat instruksi tentang pencegahan penyebaran corona virus diesease (Covid-19) di lingkungan Universitas Indonesia. Di surat edaran itu ada 10 poin dan salah satunya adalah anjuran untuk menerapkan pembelajaran daring (Yandwiputra, 2020). Ada sekitar 65 perguruan tinggi di Indonesia yang telah melaksanakan pembelajaran daring dalam mengantisipasi penyebaran Covid-19 (CNNIndonesia, 2020). Jamaluddin, D., Ratnasih, T., Gunawan, H., \& Paujiah, E. (2020) menyatakan bahwa pembelajaran daring memiliki kekuatan, tantangan dan hambatan tersendiri. Pemerintah Indonesia patut dan taat dalam penyecegahan penyebaran Covid-19, WHO memberikan himbauan untuk menghentikan acara-acara yang dapat menyebabkan massa berkerumun. Maka dari itu, pembelajaran tatap muka yang mengumpulkan banyak mahasiswa di dalam kelas ditinjau ulang pelaksanaanya. Perkuliahan harus diselenggarakan dengan skenario yang mampu mencegah berhubungan secara fisik antara mahasiswa dengan dosen maupun mahassiswa dengan mahasiswa (Firman, F., \& Rahayu, S., 2020). Menurut Milman (2015) penggunaan teknologi digital dapat memungkinkan mahasiswa dan dosen melaksanakan proses pembelajaran walaupun mereka ditempat yang berbeda.

Bentuk perkuliahan yang dapat dijadikan solusi dalam masa pandemi covid-19 adalah pembelajaran daring. Menurut Moore, Dickson-Deane, \& Galyen (2011). Sistem pembelajaran daring (dalam jaringan) merupakan sistem pembelajaran tanpa tatap muka secara langsung antara dosen dan mahasiswa tetapi dilakukan melalui online yang menggunakan jaringan internet. Memang masih banyak kendala dalam pembelajaran online ini misalnya kuota, jaringan, dan pengawasan yang minim (Hilma \& Tetep, 2020). Tetapi Dosen harus memastikan kegiatan belajar mengajar tetap berjalan, meskipun siswa berada di rumah. Solusinya, dosen dituntut dapat mendesain media pembelajaran sebagai inovasi dengan memanfaatkan media daring (online). Tugas dan tanggung jawab dosen adalah menumbuh kembangkan sikap ilmiah melalui penanaman rasa ingin tahu, baik untuk diri sendiri maupun orang lain. Hal ini disebabkan karena rasa ingin tahu tersebut merupakan dasar bagi seseorang untuk tumbuh dan berkembang secara intelektual. Aspek-aspek yang menjadi ukuran dalam mengevaluasi kinerja dosen tersebut, meliputi: kualitas hasil kerja (quality of 
work) kemampuan (capability), prakarsa (initiative), komunikasi (communication), dan ketepatan waktu (promtness). Tugas ini, merupakan utama seorang dosen yang harus dilaksanakan dengan sungguh-sungguh karena sebagai realisasi dari tugas utama suatu perguruan tinggi, yaitu melaksanakan kegiatan proses belajar mengajar dalam upaya mendidik mahasiswa.

Pembelajaran daring merupakan pembelajaran yang menggunakan jaringan internet dengan aksesibilitas, konektivitas, fleksibilitas, dan kemampuan untuk memunculkan berbagai jenis interaksi pembelajaran. Penelitian yang dikakukan oleh Zhang et al., (2004) menunjukkan bahwa penggunaan internet dan teknologi multimedia mampu merombak cara penyampaian pengetahuan dan dapat menjadi alternatif pembelajaran yang dilaksanakan dalam kelas tradisional. Pembelajaran daring adalah pembelajaran yang mampu mempertemukan mahasiswa dan dosen untuk melaksanakan interaksi pembelajaran dengan bantuan internet (Kuntarto, E. (2017). Pada tataran pelaksanaanya pembelajaran daring memerlukan dukungan perangkatperangkat mobile seperti smarphone atau telepon adroid, laptop, komputer, tablet, dan iphone yang dapat dipergunakan untuk mengakses informasi kapan saja dan dimana saja (Gikas \& Grant, 2013). Perguruan tinggi pada masa WFH perlu melaksanakan penguatan pembelajaran secara daring (Darmalaksana, 2020). Pembelajaran secara daring telah menjadi tuntutan dunia pendidikan sejak beberapa tahun terakhir $(\mathrm{He}, \mathrm{Xu}$, \& Kruck, 2014). Pembelajaran daring dibutuhkan dalam pembelajaran di era revolusi industri 4.0 (Pangondian, R. A., Santosa, P. I., \& Nugroho, E., 2019).

Sistem pembelajaran dilaksanakan melalui perangkat personal computer (PC) atau laptop yang terhubung dengan koneksi jaringan internet. Guru dapat melakukan pembelajaran bersama diwaktu yang sama menggunakan grup di media sosial seperti WhatsApp (WA), Google Classroom, Yutube, FB, telegram, instagram, aplikasi zoom ataupun media lainnya sebagai media pembelajaran. Dengan demikian, dosen dapat memastikan mahasiswanya mengikuti pembelajaran dalam waktu yang bersamaan, meskipun di tempat yang berbeda.

Penggunaan teknologi mobile mempunyai sumbangan besar dalam lembaga pendidikan, termasuk di dalamnya adalah pencapaian tujuan pembelajaran jarak jauh (Korucu \& Alkan, 2011). Berbagai media juga dapat digunakan untuk mendukung pelaksanaan pembelajaran secara daring. Misalnya kelas-kelas virtual menggunakan layanan Google Classroom, Edmodo, dan Schoology (Enriquez, 2014; Sicat, 2015; Iftakhar, 2016), dan applikasi pesan instan seperti WhatsApp (So, 2016). Pembelajaran secara daring bahkan dapat dilakukan melalui media social seperti Facebook dan Instagram (Kumar \& Nanda, 2018). Pembelajaran daring menghubungkan peserta didik dengan sumber belajarnya (database, pakar/instruktur, perpustakaan) yang secara fisik terpisah atau bahkan berjauhan namun dapat saling berkomunikasi, berinteraksi atau berkolaborasi (secara langsung/synchronous dan secara tidak langsung/asynchronous). Pembelajaran daring adalah bentuk pembelajaran jarak jauh yang memanfaatkan teknologi telekomunikasi dan informasi, misalnya internet, CD-ROOM (Molinda, 2005).

\section{KAJIAN PUSTAKA}

Pembelajaran adalah proses interaksi mahasiswa dengan dosen dan sumber belajar pada suatu lingkungan belajar. Pembelajaran pada program sarjana sebagai implementasi KKNI dalam rangka untuk tercapainya capaian pembelajaran lulusan (CPL). Untuk mencapai pembelajaran CPL yang dikelola yang tertuang di dalam rencana pembelajaran semester (RPS). Pembelajaran dalam rangka mencapai CPL menggunakan pendekatan yang berpusat 
pada mahasiswa (student centered learning disingkat SCL). Pendekatan SCL dapat menerapkan pendekatan andragogi, yaitu seni dan ilmu dalam membantu peserta didik (orang dewasa) untuk belajar dengan menerapkan pendekatan dalam konsep belajar, yakni: konsep diri; pengalaman hidup (peran pengalaman peserta didik) kesiapan belajar (kesiapan belajar), orientasi belajar (orientasi belajar). Muhammad Yusuf, S. Sohiron (2019).

Pengelolaan pembelajaran adalah suatu upaya untuk mengatur (menejemen, mengendalikan) aktivitas pembelajaran berdasarkan konsep-konsep dan prinsip-prinsip pembelajaran untuk menyukseskan tujuan pembelajaran agar tercapai secara lebih efektif, efisien, dan produktif yang diawali dengan penentuan strategi dan perencanaan, dan diakhiri dengan penilaian.Sekarang ini,mutu menjadi satusatunya hal yang sangat penting dalam dunia pendidikan. Erwinsyah A (2017).

Pembelajaran daring efektif untuk mengatasi pembelajaran yang memungkinan dosen dan mahasiswa berinteraksi dalam kelas virual yang dapat diakses dimana saja dan kapan saja. Pembelajaran daring dapat membuat mahasiswa belajar mandiri dan motivasinya meningkat. Ali Sadikin, Afreni Hamidah (2020). Dampak Pandemi Covid-19 terhadap pembelajaran meliputi: (1) Perubahan pembelajaran tatap muka menjadi pembelajaran online; (2) Peningkatan penggunaan teknologi dalam pembelajaran; (3) Peningkatan kemandirian belajar mahasiswa. (Firman, 2020)

Proses pembelajaran yang dilakukan selama masa pandemi covid 19 adalah dilakukan secara online, bentuk pembelajarannya menggunakan aplikasi. Aplikasi yang digunakan adalah aplikasi zoom, google classroom dan whatsapp group, kendala yang dihadapi adalah jaringan internet yang tidak stabil, aplikasi yang digunakan dan ilmu yang belum tersampaikan secara efektif, serta saran yang dapat diberikan adalah proses pembelajaran online dapat lebih efektif lagi kedepannya. Paul Usmany (2020)

\section{METODE PENELITIAN}

Metode penelitian yang digunakan adalah penelitian deskriptif dengan metode survey. Menurut Sugiyono (2012:29) metode deskriptif adalah metode yang digunakan untuk menggambarkan atau menganalisis suatu hasil penelitian tetapi tidak digunakan untuk membuat kesimpulan yang lebih luas. Singarimbun (1982:3) dalam metode penelitian survey mengatakan bahwa penelitian survey adalah penelitian yang mengambil sampel dari satu populasi dan menggunakan kuesioner sebagai alat pengumpulan data yang pokok. Dalam penelitian ini survey dilakukan kepada mahasiswa Fakultas Ekonomi yang telah menerima perkuliahan atau manajemen pembelajaran daring. Di dapatkan 15 orang subjek penelitian, 5 orang mahasiswa angkatan 2017, 5 orang mahasiswa angkatan 2018, dan 5 orang mahasiswa angkatan 2019, 10 orang mahasiswa berjenis kelamin laki-laki dan 5 orang mahasiswa berjenis kelamin perempuan. Pengumpulan data dilakukan melalui kuisioner google form dan wawancara via telpon atau zoom cloud meeting. Analisis data penelitian dilakukan menggunakan model analisis Miles \& Huberman (1994) yang terdiri dari tiga tahapan, yaitu reduksi data, display data, serta penarikan dan verifikasi. Analisis data penelitian tahap reduksi data merupakan tahap mengumpulkan seluruh informasi yang dibutuhkan dari hasil wawancara lalu di kelompokkan datanya. Tahap display data merupakan pemaparan data yang diperlukan dalam penelitian dan yang tidak perlu dibuang. Tahap penarikan dan verifikasi kesimpulan adalah tahap interpretasi data penelitian untuk ditarik kesimpulan berdasarkan fenomena yang didapatkan (Miles, M. B., \& Huberman, M.,1994)

\section{HASIL DAN PEMBAHASAN}


Manajemen Pembelajaran Daring Di Perguruan Tinggi Pada Masa Pandemi Covid-19 di Program Studi Manajemen fakultas Ekonomi bahwa pelaksanaan pembelajaran dilaksanakan dengan optimal walaupun dilapangan pada dasarnya mengalami banyak kendala, baik dari dosen maupun mahasiswa serta kelengkapan sarana dan prasaran penunjang atau yang berhubungan dengan hardware.

1. Inovasi dan mendesain perkuliahan secara lengkap. Perkuliahan yang dilakukan oleh dosen Fakultas Ekonomi berdasarkan hasil wawancara dan penyebaran kuisioner diperlohe bahwa, mayoritas dosen telah mendesain sedemikian rupa dalam memberikan pelayanan yang optimal kepada mahasiswa, salah satunya dengan membuat grup kelas di WA dan membuat grup belajar pada google classroom serta melakukan inovasi-inovasi lainnya seperti voice note pada WA dan video belajar. Selain itu melakukan zoom meeting dan membuat video belajar baik dikirim di wa grup atau di publish pada media sosial seperti FB dan Yutube, hal tersebut dilakukan untuk mempermudah perkuliahan pada kondisi covid -19 .

2. Bervariasinya metode pembelajaran. Metode yang digunakan oleh dosen Program Studi Fakultas Ekonomi mayoritas bervariasi ada yang melakukan metode kooperatif learning via daring, kerja kelompok, penugasan, latihan soal dan lain sebagainya. Tetapi ada beberapa dosen yang belum menggunakan metode yang sesuai, hal tersebut salah satu kendalanya dalam penguasaan teknologi, juga mereka memiliki kesibukan yang tidak sempat menyusun metode pembelajaran sesuai dengan tema perkuliahan.

3. Flatform atau aplikasi yang sesuai dengan materi perkuliahan. Berdasarkan hasil wawancara dengan mahasiswa serta menggunakan kuisioner google form bahwa dosen di prodi manajemen mayoritas sudah menggunakan flatporm pembelajaran seperti yang saat ini digunakan mayoritas dosen-dosen. Ada hal yang menarik bahwa mahasiswa juga berkeinginan untuk setiap pertemuan dengan dosen bukan sekedar memberikan tugastugas atau soal-soal, tetapi mereka berharap bahwa untuk setiap pertemuan dosen melakukan tatap muka secar langsung atau online baik menggunakan zoom meeting, atau google meet atau juga melalui video yang di share kepada mahasiswa. Kendala tersebut ada banyak dosen yang tidak melakukan perkuliahan secara tatap muka langsung. Jika dibandingkan dengan yang menggunakan perkuliahan secara live, lebih banyak yang tidak melakukan. Ini salah satunya yang menjadi harapan mahasiswa bahwa perkuliahan tetap dilaksanakan secara live via daring.

4. Adanya komunikasi yang baik dengan mahasiswa. Perkuliahan yang dilakukan di Prodi Manajemen Fakultas Ekonomi Universitas Galuh mayoritas melakukan komunikasi yang baik dengan mahasiswa, jika mereka berhalangan hadir tidak bisa memberikan perkuliahan, mereka menyiapkan materi perkuliahan dan di share pada WA grup atau google classroom. Secara keseluruhan tidak ada dosen selama satu semester untuk yang tidak masuk perkuliahan. T

5. Meminimalisir kendala biaya kuota perkuliahan daring. Untuk meminimalisir biaya kuota mahasiswa, maka setiap dosen memberikan perkuliahan bervariasi, sekali-kali menggunakan live zoom, kadang menggunakan google meet dengan dorasi waktu maksimal 1 jam minimal 30 menit, atau memebuat voice note via atau membuat video durasi pendek perkulaiahan. Minimnya kelengkapan sarana dan prasarana yang dimiliki oleh mahasiswa untuk melaksanakan pembelajaran daring. daring. Mahasiswa mengungkapkan bahwa untuk mengikuti pembelajaran daring, mereka harus mengeluarkan biaya cukup mahal untuk membeli kuota data internet. Menurut mereka, pembelajaran dalam bentuk konferensi video telah menghabiskan banyak kuota data, 
sementara diskusi online melalui applikasi pesan instan tidak membutuhkan banyak kuota. Rata-rata mahasiswa menghabiskan dana Rp. 100.000 sampai Rp. 200.000 per minggu, tergantung provider seluler yang digunakan sedangkan bantuan dari pemerintah bantuan belajar tidak cukup untuk satu bulan karena jatah untuk setiap mahasiswa sebesar $30 \mathrm{~Gb}$ untuk semua fasilitas yang diberikan oleh dosen, mendownload, video, yutube, zoom dll. Penggunaan pembelajaran daring menggunakan konferensi video membutuhkan biaya yang cukup mahal.

Kegagapan pembelajaran daring memang nampak terlihat di hadapan kita, tidak satu atau dua sekolah saja melainkan menyeluruh dibeberapa daerah di Indonesia. Komponenkomponen yang sangat penting dari proses pembelajaran daring (online) perlu ditingkatkan dan diperbaiki. Pertama dan terpenting adalah jaringan internet yang stabil, kemudian gawai atau komputer yang mumpuni,aplikasi dengan platform yang user friendly, san sosialisasi daring yang bersifat efisien, efektif, kontinyu, dan integratif kepada seluruh stekholder pendidikan. Solusi atas permasalahan ini adalah pemerintah harus memberikan kebijakan dengan membuka gratis layanan aplikasi daring bekerjasama dengan provider internet dan aplikasi untuk membantu proses pembelajaran daring ini.

\section{KESIMPULAN DAN SARAN}

Berdasarkan hasil penelitian dapat disimpulkan bahwa keberhasilan dosen dalam manajemen pembelajaran di perguruan tinggi pada masa pandemic covid-19 yaitu: 1) inovasi dan mendesain perkuliahan secara lengkap, 2) bervariasinya metode pembelajaran, 3) flatform atau aplikasi yang sesuai dengan materi perkuliahan, dan 4) adanya komunikasi yang baik dengan mahasiswa, 5) dapat meminimalisir kendala biaya kuota perkuliahan daring. Sebaiknya pemerintah mempersiapkan kurikulum dan silabus permbelajaran berbasis daring. Bagi kampus-kampus perlu untuk melakukan bimbingan teknik (bimtek) online proses pelaksanaan daring dan melakukan sosialisasi kepada orangtua dan mahasiswa melalui media cetak dan media sosial tentang tata cara pelaksanaan pembelajaran daring, kaitannya dengan peran dan tugasnya. Dalam proses pembelajaran daring, penting untuk ditambahkan pesanpesan edukatif kepada orangtua dan mahasiswa, tentang wabah pandemi Covid-19. Dengan demikian kita dapati pembelajaran yang sama dengan tatap muka tetapi berbasis online. Efeknya sangat bagus, programnya tepat sasaran, dan capaian pembelajarannya tercapai.

\section{DAFTAR PUSTAKA}

[1] Suherman A, Muyasa, Mulyasana dan Sudradjat (2018). Faktor-Faktor Determinan Terhadap Kinerja Dosen Dalam Meningkatkan Mutu Layanan Akademik Pendidikan Tinggi. http://kmp.spsuninus.ac.id/index.php/kmp/article/view/21/14.

[2] CNNIndonesia. (n.d.-a). 4 Aplikasi Video Conference yang Irit dan Boros Data.Retrieved from https://www.cnnindonesia.com/teknologi/20200330191529185-488422/4-aplikasi-video-conference-yang-irit-dan-boros-data

[3] CNNIndonesia. (n.d.-b). 65 Kampus Kuliah dari Rumah, Sultan Yogya Ragukan Efektivitas. Retrieved from https://www.cnnindonesia.com/nasional/20200316110707-20-483756/65-kampuskuliah-dari-rumah-sultan-yogya-ragukan-efektivitas

[4] Darmalaksana, W. (2020). WhatsApp Kuliah Mobile . Fakultas Ushuluddin UIN SunanGunung Djati Bandung. 
[5] Erwinsyah Alfian (2017). Manajemen pembelajaran dalam kaitannya dengan peningkatan kualitas guru. https://core.ac.uk/download/pdf/228816497.pdf

[6] Firman. (2020). Dampak Covid-19 terhadap Pembelajaran di Perguruan Tinggi. https://ojs.unsulbar.ac.id/index.php/bioma/article/download/743/406/\#: :text=Hasil\% 20penelitian\%20menunjukkan\%20bahwa\%20dampak,3)\%20Peningkatan\%20kemand irian\%20belajar\%20mahasiswa.

[7] Gikas, J., \& Grant, M. M. (2013). Mobile computing devices in higher education: Student perspectives on learning with cellphones, smartphones \& social media. Internet and Higher Education.https://doi.org/10.1016/jjheduc.2013.06.002

[8] Harnani S, (2020). Efektivitas Pembelajaran Daring Di Masa Pandemi Covid-19. https://bdkjakarta.kemenag.go.id/berita/efektivitas-pembelajaran-daring-di-masapandemi-covid-19.

[9] Hilma,H. Tetep. (2020). Efektivitas Pembelajaran PPKN Berbasis Daring terhadap Partisipasi Belajar Peserta Didik di SMAN 11 Garut. Jurnal Civicos Vol 4. No. 1. Tahun 2020.

https://journal.institutpendidikan.ac.id/index.php/journalcss/article/view/872/655. DOI: https://doi.org/10.31980/civicos.v4i1.872 (Diunduh 05 Nopember 2020).

[10] Masri Singarimbun dan Sofian Effendi. 1982. Metode Penelitian Survai. Jakarta: Lembaga Penelitian, Pendidikan dan Penerangan Ekonomi dan Sosial (LP3ES).

[11] Miles, M. B., \& Huberman, M. (1994). Qualitative Data Analysis Second Edition. SAGE Publications.

[12] Milman, N. B. (2015). Distance Education. In International Encyclopedia of the Social \& Behavioral Sciences: Second Edition.https://doi.org/10.1016/B978-0-08097086-8.92001-4

[13] Moore, J. L., Dickson-Deane, C., \& Galyen, K. (2011). E-Learning, online learning, and distance learning environments: Are they the same? Internet and Higher Education. https://doi.org/10.1016/jiheduc.2010.10.001.

[14] Pangondian, R. A., Santosa, P. I., \& Nugroho, E. (2019). Faktor-Faktor Yang Mempengaruhi Kesuksesan Pembelajaran Daring Dalam Revolusi Industri 4.0. InSeminar Nasional Teknologi Komputer \& Sains (SAINTEKS)(Vol. 1, No. 1).

[15] Paul Usmany (2020). Dampak Pandemi Covid-19 Terhadap Proses Pembelajaran Online. https://ojs3.unpatti.ac.id/index.php/jak/article/view/2709

[16] Sadikin A, Hamidah A. (2020). Pembelajaran Daring di Tengah Wabah Covid-19 (Online Learning in the Middle of the Covid-19 Pandemic). https://doi.org/10.22437/bio.v6i2.9759

[17] Sugiyono. 2012. Metode Penelitian Pendidikan Pendekatan Kuantitatif, Kualilatif, dan R\&D. Bandung: Alfabeta.

[18] Yandwiputra, A. R. (n.d.). Kuliah Jarak Jauh karena Virus Corona, UI: Bukan Lockdown. Retrieved from https://metro.tempo.co/read/1319537/kuliah-jarak-jauhkarena-virus-corona-ui-bukan-lockdown

[19] Yusuf M, Sohiron s. (2019). Manajemen pembelajaran pendidikan tinggi (implementasi kurikulum berbasis kkni pada program sarjana melalui pendekatan andragogi). http://ejournal.uin-suska.ac.id/index.php/IJIEM/article/view/7897

[20] Zhang, D., Zhao, J. L., Zhou, L., \& Nunamaker, J. F. (2004). Can e-learning replace classroom learning? Communications of the ACM. https://doi.org/10.1145/986213.986216. 